\title{
Enamel matrix derivative and bone grafts for periodontal regeneration of intrabony defects. A systematic review and meta-analysis
}

Matarasso M., Iorio-Siciliano V., Blasi A., Ramaglia L., Salvi G. E. \& Sculean A.

\section{Matarasso M.}

Department of Periodontology, School of Dental Medicine, University of Naples "Federico II",

Via Sergio Pansini 5 -80131-Napoli, Italy

Iorio-Siciliano V., Blasi A.

School of Oral Surgery, School of Dental Medicine, University of Naples "Federico II ", Via Sergio Pansini 5 -80131-Napoli, Italy

\section{Ramaglia L.}

Head of School of Oral Surgery, School of Dental Medicine, University of Naples “ Federico II",

Via Sergio Pansini 5 -80131-Napoli, Italy

Salvi G.E., Sculean A.

University of Bern, School of Dental Medicine, Department of Periodontology, Freiburgstrasse 7, 3010 Bern, Switzerland

\section{Corresponding author:}

Anton Sculean

University of Bern, School of Dental Medicine, Department of Periodontology

Freiburgstrasse 7, 3010 Bern,

Switzerland

e-mail: anton.sculean@zmk.unibe.ch

Running title: Regenerative treatment of intrabony defects

Keywords: intrabony defect, periodontal disease, enamel matrix derivative, bone graft, periodontal pocket, periodontal regeneration 


\section{Abstract}

Objective: To assess the clinical efficacy of regenerative periodontal surgery of intrabony defects using a combination of enamel matrix derivative (EMD) and bone graft compared with that of EMD alone.

Materials and methods: The Cochrane Oral Health Group specialist trials, MEDLINE and EMBASE databases were searched for entries up to February 2014. The primary outcome was gain of clinical attachment (CAL). Weighted means and Forest plots were calculated for CAL gain, probing depth (PD) and gingival recession (REC).

Results: Twelve studies reporting on 434 patients and 548 intrabony defects were selected for the analysis. Mean CAL gain amounted to $3.76 \pm 1.07 \mathrm{~mm}$ (median 3.63 95\% Cl: 3.51-3.75) following treatment with a combination of EMD and bone graft and to $3.32 \pm 1.04 \mathrm{~mm}$ (median 3.40; $95 \% \mathrm{Cl} 3.28$; 3.52) following treatment with EMD alone. Mean PD reduction measured $4.22 \pm 1.20 \mathrm{~mm}$ (median 4.10; 95\%Cl3.96-4.24) at sites treated with EMD and bone graft and yielded $4.12 \pm 1.07 \mathrm{~mm}$ (median $4.00 ; 95 \% \mathrm{Cl} 3.88$ 4.12) at sites treated with EMD alone. Mean REC increase amounted to $0.76 \pm 0.42 \mathrm{~mm}$ (median $0.63 ; 95 \% \mathrm{Cl} 0.58-0.68$ ) at sites treated with $\mathrm{EMD}$ and bone graft, and to $0.91 \pm 0.26 \mathrm{~mm}$ (median 0.90; 95\%Cl0.87-0.93) at sites treated with EMD alone.

Conclusions: Within their limits, the present results indicate that the combination of EMD and bone grafts may result in additional clinical improvements in terms of CAL gain and PD reduction compared with those obtained with EMD alone. The potential influence of the chosen graft material or of the surgical procedure (i.e. flap design) on the clinical outcomes is unclear.

Clinical relevance: The present findings support the use of EMD and bone grafts for the treatment of intrabony periodontal defects. 


\section{Introduction}

Periodontitis is an infectious disease triggered by periodontal pathogenic bacteria and is characterized by pocket formation and attachment loss, ultimately affecting tooth survival [1]. Besides the anti-infectious therapy aiming to eliminate or reduce the periodontal pathogenic flora in order to arrest the destruction process, one important goal is to reconstruct the bone defects caused by the infectious process [2,3]. During the last decades, various treatment modalities such as the use different bone grafting materials, guided tissue regeneration (GTR), enamel matrix derivative (EMD) or combinations thereof have been used to predictably regenerate the lost tooth`s supporting tissues including root cementum, periodontal ligament, alveolar bone and gingiva [2, 3].

Narrative and systematic reviews have provided evidence indicating that the use of EMD in conjunction with open flap debridement (OFD) significantly improved the clinical outcomes in intrabony defects compared with OFD alone (OFD) [4-6]. In several studies [7-10] it was recognized that the morphology of the osseous defect plays an important role in the healing capacity of the defect itself. For example, in the presence of noncontained defects, the use of a non-resorbable titanium-reinforced membrane or the combination of a resorbable membrane with a grafting material has been advocated [11]. Is has been also shown that the use of biomaterials without space-making properties such as EMD may not be sufficient for the treatment of deep non-contained intrabony defects. In fact, the results of a clinical study using EMD alone for the treatment of intrabony defects [12] showed that three-walls defects yielded a 2.7x higher probability of gaining at least $3 \mathrm{~mm}$ of CAL compared with that of one-wall defects. In a randomized controlled clinical trial, the application of a non-resorbable titanium-reinforced membrane increased by $7 x$ the probability of obtaining a significant CAL gain of at least $4 \mathrm{~mm}$ compared with the application of EMD alone in the treatment of non-contained intrabony defects [13]. Therefore, in order to maximize the clinical outcomes by stabilizing the blood clot and preventing flap collapse, the combination of EMD and bone grafts has been proposed [14, 15].

Results from a recent series of studies evaluating EMD adsorption to the surface of various types of bone grafts such as for example a demineralized bovine bone mineral (DBBM), have shown that this combination can stimulate the release of growth factors and cytokines including bone morphogenetic protein 2 and transforming growth factor beta 1. Moreover, there were significantly higher mRNA levels of osteoblast 
differentiation markers including collagen $1 a 1$, alkaline phosphatase and osteocalcin in osteoblasts and PDL cells cultured on EMD-coated DBBM particles thus suggesting that EMD enhances osteoblast and PDL cell attachment, proliferation and differentiation on DBBM particles and provides a biologic rationale for using this combination in regenerative periodontal therapy [16]. Thus, the available clinical and biological data appear to support the combination of EMD and bone grafts for regenerative treatment in intrabony defects. It is also anticipated that this combination may even yield to synergistic effects where the graft material may act as an osteoconductive scaffold maintaining in the same time the defect space, while EMD may induce formation of root cementum, periodontal ligament and bone [14-16].

Despite the fact that in recent years, different combinations of EMD and bone grafts including autogenous bone [17-19], demineralized freeze dried bone allograft (DFDBA) [20-22], DBBM [23-30], and alloplastic materials [31-37] have been used to regenerate intrabony defects, the outcomes showed great variability. Thus, at the time being, it is still unclear to what extent the combination of EMD and different graft materials may lead to additional clinical improvements compared to the use of EMD alone. At present, according to the best of our knowledge, no data from systematic reviews including metaanalysis are available and thus, the magnitude of the clinical improvements that can be obtained following the combination approach over the use of EMD alone is still unclear. Therefore, the aim of the present systematic review and meta-analysis was to assess the clinical efficacy of regenerative periodontal surgery in intrabony defects using a combination of enamel matrix derivative (EMD) and bone grafts compared with the application of EMD alone. 


\section{Materials and Methods}

This systematic review was prepared by following the recommendations by Needleman et al. [38] and the PRISMA principles (Preferred Reporting Items for Systematic Reviews and Meta-analysis) [39].

\section{Focused question}

The focused question was formulated according to the Population Intervention Control Outcome (PICO) principle "In patients with intrabony defects, what are the clinical benefits of using a combination of enamel matrix derivative (EMD) and bone graft compared with EMD alone".

\section{Search strategy}

The search was conducted on electronic databases up to February 2014. The search was applied to the Cochrane Oral Health Group specialist trials, MEDLINE and EMBASE.

The strategy used was a combination of MeSH (Medical Subject Headings) terms and free text words: «surgical flaps » $[\mathrm{MeSH}] \mathrm{OR}$ « periodontal pocket surgery » $[\mathrm{MeSH}]$ or «periodontal regeneration » [text words] OR « intra bony defect» [text word] OR « intrabony defect » [text word] OR « infra bony defect» [text word] OR « infrabony defect » [text word] OR « intra-bony defect » [text word] OR « intra osseus » [text word] OR « intraosseus » [text word] OR « intra-osseous » [text word] OR « amelogenin » [text word] OR « biological factor » [text word] OR « biological growth factor » [text word] OR « bone graft » [text word] OR « bone substitute » [text word] OR « autogenous bone » [text word] OR « deproteinized bovine bone mineral » [text word] OR « bone mineral » [text word] OR « xenograft » [text word] OR «emd» [text word] OR « EMD » [text word] OR « enamel matrix protein » [text word] OR « enamel protein » [text word] OR « dental enamel protein » [text word] OR « enamel matrix derivative » [text word] « alloplastic » [ text word] OR «allogenic » [text word] OR «longitudinal study» [MeSH] OR «randomized controlled study [MeSH] OR «controlled study» [MeSH] OR «comparative study $[\mathrm{MeSH}] \mathrm{OR}$ «clinical trial» $[\mathrm{MeSH}]$ «combination therapy AND intrabony defect » [text word] « combination therapy AND intrabony defects » [text word]. 
Hand search included a search of Journal of Clinical Periodontology, Journal of Periodontology, Journal of Periodontal Research, International Journal of Periodontics and Restorative Dentistry and Clinical Oral Investigations.

\section{Inclusion Criteria}

The studies were included on the basis of the following criteria:

- English language

- Randomized Clinical Trials (RCT) comparing EMD + bone graft with EMD alone

- Controlled Clinical Trials (CCT) comparing EMD + bone graft with EMD alone

- Studies with a mean follow-up period between 6 and 24 months

- Defect sites with Pocket Depth (PD) $\geq 5 \mathrm{~mm}$

- Intrabony defect depth $\geq 3 \mathrm{~mm}$

\section{Exclusion Criteria}

- Studies based on questionnaire or interview

- Radiographic studies

- Studies with only histological data

- Studies on furcation defects

- Studies on supra-osseous defects

- RCT or CCT comparing EMD + Bone Graft with Open Flap Debridement (OFD)

- $\quad$ RCT or CCT comparing EMD + Bone Graft with Guided Tissue Regeneration (GTR)

- $\mathrm{RCT}$ or CCT comparing EMD+Bone graft with Bone graft alone 


\section{Data extraction and analysis}

The titles identified by the search, were screened independently by two reviewers (M.M. and V.I.S.). The abstract of all studies of possible relevance were obtained and screened independently by the reviewers. When studies met the inclusion criteria or when insufficient data from abstracts were available to evaluate inclusion criteria, the full-text article was obtained. The selected papers were screened independently by the reviewers to confirm whether they met the inclusion criteria or not. The inter-examiner agreement was analyzed by kappa coefficient. Any discrepancy between the two reviewers was resolved via discussion. Data were extracted independently by the two examiners (M.M and V.I.S.). If the reviewers had data-related questions, the authors of the selected papers were contacted.

\section{Outcome measures}

The primary outcome measure (i.e. true end-point outcome) included:

- Change in clinical attachment level (CAL)

The secondary outcome measures (i.e. surrogate end-point outcomes) included:

- Change in probing depth (PD)

- Change in gingival recession (REC)

\section{Methodological quality assessment}

With respect to randomized controlled trials (RCTs) and controlled clinical trials (CCTs), quality assessment was performed by means of the Cochrane Collaboration's tool for assessing risk of bias (www.cochrane-handbook.org). 


\section{Data analysis}

Study outcomes are reported by means of evidence tables and a quantitative synthesis by means of a meta-analysis.

For data analysis, EpiDat software (EpiDat version 3.1 for Windows, Dirección Xeral de Innovación e Xestión da Saúde Pública de Galicia - SPAIN) was used. Mean differences and $95 \%$ Confidence Intervals of differences $(95 \% \mathrm{Cl})$ were calculated for PD, CAL and REC. Statistical heterogeneity was evaluated by DerSimonian-Laird's test, where $p$ values below 0.05 were considered heterogeneous. The degree of inconsistency was verified by the $I^{\wedge} 2$ test. An analysis by sub-groups was performed considering the different grafts associated with EMD using the random effects model due to the heterogeneity detected. The Forest plot was utilized to illustrated the weighted mean of the outcome in each study and the final estimate. 


\section{Results}

From an original yield of 12.288 titles and 152 abstracts, 15 studies were selected for the full-text analysis. Three studies were excluded and a total of 12 studies were selected for the analysis (Fig.1). Reasons for exclusion are summarized in Table 1. One study [35] was excluded because it reported only 6 months results and the same data were used in another publication with a follow-up of 1 year [36]. Two studies [33, 37] were excluded because an observation time of 4 years was reported.

\section{Study characteristics}

The summary of quality assessment was described in Table 2. In the randomized controlled clinical trials four studies $[19,23,26,34]$ had a high risk of bias.

Descriptive data relative to the included twelve studies are reported in Table 3. Only one study was not specifically designed to test the combination of EMD and bone graft compared with EMD alone [30] whereas for the other studies, data were extracted from the original samples. All studies were randomized controlled clinical trials (RCTs). In ten studies a simple randomization was performed, whereas only in two studies $[28,30]$ a balanced block randomization was done. Eight studies were single-blinded $[14,18,26$, $28,32,34,36]$, one was double blind [23], whereas in only one study the masking was not performed [19] and in two studies these data were not available [30, 31]. In all studies a power calculation was performed with the exception of three studies [20, 23, 36]. Two studies were conducted in private practice [14, 30], whereas one study was conducted both in private practice and in university [28]. Outcomes of other studies were not reported. Six different types of intervention were tested: in four studies a combination of EMD and DBBM was analyzed [23, 26, 28, 30], two studies were conducted using a

combination of EMD and autologous bone graft $[18,19]$, while two studies tested a 
combination of EMD and Bioglass [31, 32]. A combination of hydroxyapatite and $\beta$ tricalcium phosphate $(\mathrm{HA}+\beta-\mathrm{TCP})$ was used in two publications $[14,36]$. The combination of EMD and DFDBA was tested in two studies $[20,21]$ while that of EMD and $\beta$-TCP was evaluated in one study [34]. The follow-up period varied between the studies (i.e., 6 months in two studies [20,23], from 6 to 8 months in one study [26], 8 months in one study [32], 12 months in seven studies [18, 19, 28, 30, 31, 34, 36] 24 months in one study [14].

\section{Patient's characteristics}

The studies reported a total of 434 patients (189 males and 245 females) with an age range between 19 and 76 years. Sixty-eight patients were tobacco smokers. Only one paper did not report smoking habits [20]. Five drop-outs were reported in three studies $[14,34,36]$. Patients enrolled in four studies suffered from chronic periodontitis $[18,28$, $32,36]$, whereas in one study patients suffering from chronic and aggressive periodontitis [19] and in another study periodontitis was defined as moderate to advanced [26]. The other paper did not report about periodontal status (Tab.4).

\section{Tooth and defect characteristics at baseline}

The studies reported a total of 548 teeth with different morphology of intrabony defects (one defect per tooth). In four papers 1,2,3 walls intrabony defects were treated [20, 30, $31,34]$, whereas in three publications 2 - and 3-wall defects were selected $[18,23,26]$. Four studies focused on $1-2$ wall defects $[14,19,32,36]$. In only one study the data about defect morphology was not available [28]. The percentage of sites with BoP+ was recorded only in three publications $[18,31,34]$ (Tab.5). 


\section{Clinical and intra-surgical characteristics of defects at baseline}

Table 6 illustrates baseline characteristics of the included defects, surgical approach performed and the use of systemic antibiotics. At baseline mean PD was $8.18 \pm 2.86$ (median 7.74; 95\% Cl 6.86-8.62), mean CAL was 9.95 \pm 3.16 (median 9.80; 95\%Cl 8.4511.15 ) and mean REC was $1.53 \pm 1.24$ (median $1.10 ; 95 \% \mathrm{Cl} 0.95-1.25$ ) for intrabony defects treated with a combination of EMD and bone graft. The sites treated with EMD alone showed a mean PD, CAL and REC of $9.09 \pm 2.86$ (median $8.20 ; 95 \% \mathrm{Cl} 7.26-9.14$ ), 10.90 \pm 3.17 (median $10.10 ; 95 \% \mathrm{Cl} 8.71-11.49$ ) and 2.96 \pm 1.29 (median $1.10 ; 95 \% \mathrm{Cl}$ 0.95-1.25) respectively. All studies reported PD values at baseline, whereas in three studies CAL and REC were not available [23, 26, 32]. During the surgical phases the mean distances CEJ-BD and INFRA were 9.38 \pm 3.08 (median 6.70; 95\%CI 5.21-8.19) and $5.50 \pm 2.35$ (median $5.20 ; 95 \% \mathrm{Cl} 4.40-6.00$ ) respectively at sites treated with a combination of EMD and bone graft, while intrabony defects treated with EMD alone showed a mean CEJ-BD of $9.48 \pm 3.10$ (median $6.80 ; 95 \% \mathrm{Cl} 5.29-8.31$ ) and INFRA of $5.52 \pm 2.36$ (median $4.90 ; 95 \% \mathrm{Cl} 4.15-5.65$ ). The mean CEJ-BD was reported in four studies $[14,19,30,31]$. Only four studies did not record INFRA $[23,26,34,36]$. In four studies a conventional flap with papilla preservation technique (MPPT or SPPT) was made $[14,19,28,36]$. Microsurgical approaches with papilla preservation technique were performed in two studies $[30,34]$ while in five studies the surgical flap was elevated without papilla preservation technique $[20,23,26,31,32]$. In one study data about the use of papilla preservation technique was not available [18]. Systemic antibiotics were not prescribed in one study [30], whereas in two papers these data were not reported [31, 36] (Tab.6). 


\section{Changes in BOP, PD, CAL, REC}

In table 7 clinical changes in terms of BOP, PD, CAL and REC changes are summarized. According to the results of the meta-analysis with inclusion of the 12 studies, high statistical heterogeneity was detected in the analysis of PD, CAL and REC $(p<0.00001$ $I^{\wedge} 2=41,62 \% ; \quad p<0.00001 \quad I^{\wedge} 2=39,16 \% ; \quad p<0.00001 \quad I^{\wedge} 2=31,96 \%$ respectively). The percentage of sites with BoP+, were collected in 3 studies $[18,34,36]$. Forest plots of PD change are depicted in Fig.2. Mean PD reduction was 4.22 \pm 1.20 mm (median 4.10; 95\% $\mathrm{Cl} 3.96-4.24)$ at sites treated with EMD and bone graft and 4.12 $\pm 1.07 \mathrm{~mm}$ (median 4.00; 95\% Cl 3.88-4.12) at sites treated with EMD alone. Mean difference of $0.05 \mathrm{~mm}(\mathrm{Cl} 95 \%$ $-0.12-0.21$ ) was calculated. The forest plot depicted in Fig. 3 illustrates the CAL gain after surgical interventions. Mean CAL gain was 3.76 \pm 1.07 mm (median $3.63 ; 95 \% \mathrm{Cl} 3.51$ 3.75) for the intrabony defects treated with combination of EMD and bone graft, and $3.32 \pm 1.04 \mathrm{~mm}$ (median $3.40 ; 95 \% \mathrm{Cl} 3.28-3.52$ ) for the defects treated with $\mathrm{EMD}$ alone. Mean difference of $0.37 \mathrm{~mm}(\mathrm{Cl} 95 \% 0.20-0.54)$ was noted. The forest plot in Fig. 4 demonstrates the REC increase at teeth treated with either EMD alone or with the combination approach. At sites treated with EMD and bone graft a mean REC increase of $0.76 \pm 0.42 \mathrm{~mm}$ (median $0.63 ; 95 \% \mathrm{Cl} 0.58-0.68$ ) was recorded, while at sites treated with EMD alone the mean REC increase amounted to $0.91 \pm 0.26 \mathrm{~mm}$ (median $0.90 ; 95 \% \mathrm{Cl}$ 0.87-0.93). Mean difference measured $0.35 \mathrm{~mm}$ (Cl 95\% -0.52-0.19). 


\section{Tooth survival rates and complications}

Survival rate and complications are presented in table 8 . No tooth was lost during the follow-up and the survival rate was $100 \%$. In eight studies flap dehiscences were not noted $[20,23,26,28,30,31,32,34]$, whereas in the other studies these data are not available for the analysis. Only three studies reported data about primary wound healing of interdental space $[14,30,34]$. The outcomes related to the number of residual pocket depth $\geq 5 \mathrm{~mm}$ are not available for the analysis. In one study one site with attachment loss was recorded [31], while no attachment loss was noted in three publications [19, 30, 34]. These data were not available for analysis in the other studies.

\section{Discussion}

The present systematic review has evaluated the efficacy of combining EMD and bone grafts compared with the use of EMD alone in the treatment of periodontal intrabony based on existing RCTs. The outcomes indicate that treatment of periodontal intrabony defects using a combination of EMD and bone grafts appears to represent a predictable treatment modality. Unfortunately, there are few well-designed clinical studies evaluating the efficacy of these regenerative surgical protocols. The primary outcome variable selected was the CAL change after a mean follow-up period varying from 6 to 24 months. The evaluation period of 6 to 24 months was selected, due to the fact that this is the time frame used in the most clinical studies to evaluate the outcomes of reconstructive periodontal surgery.

The findings from the meta-analysis have demonstrated significantly better CAL gain and PD reduction in the defects treated with EMD and bone grafts when compared with the 
healing of the defects treated using EMD alone. Hence, the outcomes from the metaanalysis suggest that the use of EMD with bone graft improve better results in terms of CAL gain and PD reduction. These data are in agreement with a recent narrative review, which has assessed the biologic rationale and potential clinical benefit of a combination EMD and bone grafts in the treatment of deep intrabony defects [40]. The authors concluded that although a clinical benefit of the combination approach was observed, direct evidence supporting this concept is still missing and further controlled clinical trials are required to explain the large variability that exists amongst the selected studies. However, the results of the present systematic review must be interpreted with caution. First of all, it should be kept in mind that in this meta-analysis, the outcomes of regenerative surgery performed in defects with different types of morphology (i.e. 1, -2 -3 walled and combinations thereof), using different types of grafts and surgical techniques have been combined. Secondly, the lack of consistency and standardization may have contributed to the high heterogeneity of the results. Furthermore, due to the lack of data, no meta-analysis could be performed on defect morphology and surgical flap designs, which are well known factors influencing the outcomes following regenerative therapy $[11,12]$. In many studies selected for the final analysis, the data about the management of interdental papilla and the primary would closure during early wound healing was not reported. While in most studies a conventional flap was performed, in two studies [30, 34] a minimally surgical approach was used. Those two studies reported CAL gains of 4.0 $\pm 1.0 \mathrm{~mm}$ and $3.7 \pm 1.3 \mathrm{~mm}$ respectively, but the micro-surgical approach did not seem to influence the healing. Interestingly, the data reported in these two studies are in agreement with the outcomes reported in the other studies included in the present metaanalysis.

Despite the fact that tooth survival rate was $100 \%$ using both regenerative approaches, none of the studies reported on the outcomes in terms of residual pockets $\geq 5 \mathrm{~mm}$. 
Furthermore, in most studies, no data on sites with attachment loss following regenerative surgery were recorded. In three papers $[19,30,34]$ no sites with attachment loss were recorded, while only one paper mentioned [31] one site with attachment loss.

An interesting finding of the present meta-analysis was the statistically significantly better outcome in terms of REC increase following treatment with EMD alone. While the biological or clinical background for this finding is a matter of speculation, the heterogeneity of surgical techniques and defects may serve as explanation.

\section{Conclusion}

Within their limits, the present results indicate that the combination of EMD and bone grafts may result in additional clinical improvements in terms of CAL gain and PD reduction compared with those obtained with EMD alone. The potential influence of the chosen graft material or of the surgical procedure (i.e. flap design) on the clinical outcomes is unclear.

\section{Compliance with Ethical Standards}

\section{Source of funding}

The present study was funded by the author`s own institution.

\section{Conflict of interest}

The authors do not report any conflict of interest related to this study.

Since the study is was a systematic review with meta-analysis, no ethical approval was required. 


\section{References}

1. Pihlström BL, Michalowicz BS, Johnson NW (2005) Periodontal disease. Lancet 366:1809-1820

2. Ivanovic A, Nikou G, Miron RJ, Nikolidakis D, Sculean A (2014) Which biomaterials may promote periodontal regeneration in intrabony periodontal defects? A systematic review of preclinical studies. Quintessence Int 45:385-395

3. Sculean A, Nikolidakis D, Nikou G, Ivanovic A, Chapple IL, Stavropoulos A (2015) Biomaterials for promoting periodontal regeneration in human intrabony defects. $A$ systematic review. Periodontology 2000 68: 182-216.

4. Sculean A, Miron R, Salvi GE, Bosshardt DD (2011) Enamel Matrix Proteins and Periodontal Wound Healing and Regeneration. Clin Adv Periodontics 1:101-117

5. Esposito M, Grusovin MG, Papanikolaou N, Coulthard P, Worthington HV (2009) Enamel matrix derivative (Emdogain) for periodontal tissue regeneration in intrabony defects. Cochrane Database Syst Rev 4: CD003875

6. Koop R, Mareheb J, Quirynen M (2012) Periodontal regeneration with enamel matrix derivative in reconstructive periodontal therapy: a systematic review. $\mathrm{J}$ Periodontol 83:707-720

7. Tonetti MS, Pini-Prato G, Cortellini P (1993) Periodontal regeneration of human intrabony defects.IV. Determinants of healing response. J Periodontol 64:934-940

8. Silvestri M, Sartori S, Rasperini G,Ricci G,Rota C, Cattaneo V (2003) Comparison of intrabony defects treated with enamel matrix derivative versus guided tissue regeneration with a nonresorbable membrane. J Clin Periodontol 30:386-393

9. Tonetti MS, Fourmousis I, Suvan J, Cortellini P, Brägger U, Lang NP European Research Group on Periodontology (ERGOPERIO) (2004) Healing, post-operative morbidity and patient perception of outcomes following regenerative therapy of deep intrabony defects. J Clin Periodontol 31:1092-1098

10. Sculean A, Kiss A, Miliauskaite A, Schwartz F, Arweiler NB, Hannig M (2008) Tenyears results following treatment with an enamel matrix proteins and guided tissue regeneration. J Clin Periodontol 35:817-824

11. Cortellini P, Tonetti MS (2000) Focus on intrabony defects: guided tissue regeneration. Periodontol 2000 22: 104-132

12. Tonetti MS, Lang NP, Cortellini P, Suvan JE, Adriaens P, Dubravec D, Fonzar A, Fourmousis I, Mayfield L, Rossi R, Silvestri M, Tiedermann C, Topoll H, Vangsted T, Wallkamm B (2002) Enamel matrix proteins in the regenerative therapy of deep intrabony defects. J Clin Periodontol 29: 317-325

13. Iorio Siciliano V, Andreuccetti G, Iorio Siciliano A, Blasi A, Sculean A, Salvi GE (2011) Clinical outcomes after treatment of non-contained intrabony defects with enamel matrix derivative or guided tissue regeneration: a 12-month randomized controlled clinical trial. J Periodontol 82: 62-71

14. De Leonardis D, Paolantonio M (2013) Enamel matrix derivative alone or associated with a synthetic bone substitute in the treatment of 1-to 2-wall periodontal defects. J Periodontol 84: 444-455

15. Iorio-Siciliano V, Andreuccetti G,Blasi A, Matarasso M, Sculean A, Salvi GE (2014) Clinical outcomes after treatment of non-contained intrabony defects using a deproteinized bovine bone mineral combined with either enamel matrix derivative or guided bone regeneration. J Periodontol 85: 1342-135016. 
16. Miron RJ, Wei L, Bosshardt DD, Buser D, Sculean A, Zhang Y (2014) Effects of enamel matrix proteins in combination with a bovine-derived natural bone mineral for the repair of bone defects. Clin Oral Investig 18:471-47

17. Trombelli L, Annunziata M, Belardo S, Farina R, Scabbia A,Guida L (2006) Autogenous bone graft in conjuction with enamel matrix derivative in the treatment of deep periodontal intra-osseous defects: a report of 13 consecutively treated patients. J Clin Periodontol 33:69-75

18. Yilmaz S, Cakar G, Yildirim B, Sculean A (2010) Healing of two and three wall intrabony periodontal defects following treatment with an enamel matrix derivative combined with autogenous bone. J Clin Periodontol 37:544-550

19. Guida L, Annunaziata M, Belardo S, Farina R, Scabbia A, Trombelli L (2007) Effect of autogenous cortical bone particulate in conjuction with enamel matrix derivative in the treatment of periodontal intraosseous defects. J Periodontol 78:231-238

20. Gurinsky BS, Mills MO, Melloning JT (2004) Clinical evaluation of demineralized freeze-dried bone allograft and enamel matrix derivative versus enamel matrix derivative alone for the treatment of periodontal osseous defects in human. $\mathrm{J}$ Periodontol 75:1309-1318

21. Aspriello SD, Ferrante L, Rubini C, Piemontese M (2011) Comparative study of DFDBA in combination with enamel matrix derivative versus DFDBA alone for treatment of periodontal intrabony defects at 12-months post-surgery. Clin Oral Investig 15:225-232

22. Hoidal MJ, Grimard BA, Mills MP, Schoofield JD, Melloning JT, Mealey BL (2008) Clinical evaluation of demineralized freeze-dried bone allograft with and without enamel matrix derivative for the treatment of periodontal osseous defects in human. J Periodontol 79:2273-2280

23. Lekovic V, Camargo PM, Weinlaender M, Nedic M, Aleksic Z, Kenney EB (2000) A comparison between enamel matrix proteins used alone or in combination with bovine porous bone mineral in the treatment of intrabony periodontal defects in humans. J Periodontol 71: 1110-1116

24. Lekovic V, Camargo PM, Weilaender M, Vasilic N, Djordjevic M, Kenney EB (2001) The use of bovine porous bone mineral in combination with enamel matrix proteins or with autologous fibrinogen/fibronectin system in the treatment of intrabony periodontal defects in humans. J Periodontol 72:1157-1163

25. Scheyer ET, Velasques-Plata D, Brunsvold MA, Lasho DJ, Melloning JT (2002) A clinical comparison of a bovine-derived xenograft used alone and in combination with enamel matrix derivative for treatment of periodontal osseous defects in humans. J Periodontol 73:423-432

26. Velasquez-Plata D, Scheyer ET, Melloning JT (2002) Clinical comparison of an enamel matrix derivative used alone or in combination with a bovine-derived xenograft for the treatment of periodontal osseous defects in humans. $\mathrm{J}$ Periodontol 73: 433-440

27. Sculean A, Windish P, Keglevich T, Chiantella GC, Gera I, Donos N (2003) Clinical and histological evaluation of human intrabony defects treated with an enamel matrix protein derivative combined with a bovine-derived xenograft. Int $\mathrm{J}$ Periodontics Restorative Dent 23: 47-55

28. Zucchelli G, Amore C, Montebugnoli L, De Sanctis M (2003) Enamel matrix proteins and bovine porous mineral in the treatment of intrabony defects:a comparative controlled trial. J Periodontol 74:1725-1735

29. Sculean A, Chiantella GC, Arweiler NB, Becker J, Schwarz F, Stavropoulos A (2008) Five year clinical and histologic results folowing treatment of human 
intrabony defects with enamel matrix derivative combinedwith a natural bone mineral. Int J Periodontics Restorative Dent 28: 153-161

30. Cortellini P, Tonetti MS (2011) Clinical and radiographic outcomes of the modified minimally invasive technique with or without regenerative materials: a randomizedcontrolled trial in intra-bony defects. J Clin Periodontol 38:365-373

31. Sculean A, Pietruska M, Schwarz F, Willershausen B, Arweiler NB, Auschill TM (2005) Healing of human intrabony defects following regenerative periodontal therapy with enamel matrix protein derivative alone or combined with a bioactive glass. A controlled clinical study. J Clin Periodontol 32: 111-117

32. Kuru B, Ylmaz S, Argin K, Noyan U (2006) Enamel matrix derivative alone or in combination with a bioactive glass in wide intrabony defects. Clin Oral Investig 10: 227-234

33. Sculean A, Pietruska M, Arweiler TM, Nemcovsky C (2007) Four year results of a prospective-controlled clinical study evaluating healing of intra-bony defects following treatment with an enamel matrix protein derivative alone or combined with a bioactive glass. J Clin Periodontol 34: 507-513

34. Bokan I, Bill JS, Schlagenhauf U (2006) Primary flap closure combined with Emdogain alone or Emdogain and Cerasorb in the treatment of intra-bony defects. J Clin Periodontol 33:885-893

35. Jepsen S, Topoll H, Rengers H, Heinz B, Teich M, Hoffmann T, Al-Machot E, Meyle J, Jervoe-Storm PM (2008) Clinical outcomes after treatment of intrabony defects with EMD/synthetic bone graft or EMD alone: a multicentre randomizedcontrolled trial. J Clin Periodontol 35:420-428

36. Meyle J, Hoffmann T, Topoll H, Heinz B, Al-Machot E, Jervoe-Storm PM, Meiss C, Eickholz P, Jepsen S (2011) A multi-centre randomized controlled clinical trial on the treatment of intra-bony defects with enamel matrix derivatives/syntetic bone graft or enamel matrix derivative alone: results after 12 months. J Clin Periodontol 38: $652-660$

37. Pietruska M, Pietruski J, Nagy K, Brecx M, Arweiler NB, Sculean A (2012) Fouryear results following treatment of intrabony periodontal defects with enamel matrix derivative alone or combined with a biphasic calcium phosphate. Clin Oral Investig 16: 1191-1197

38. Needlemann IG (2002) A guide to systematic reviews. J Clin Periodontol 29:6-9

39. Liberati A, Altman DG, Tetziaff J, Mulrow C, Gotzsche PC, loannidis JP, Clarke M, Devereaux PJ, Kleijnen J, Moher D (2009) The PRISMA statement for reporting systematic reviews and meta-analysis of studies that evaluate health care interventions: explanation and elaboration. Journal of Clinical Epidemiology 62: e1-e34

40. Miron RJ, GuillemetteV, Zhang Y, Chandad F, Sculean A (2014) Enamel matrix derivative in combination with bone grafts: A review of the literature. Quintessence Int 45:475-487 
Tab.1 Studies excluded at full-text analysis

\begin{tabular}{|ll|}
\hline Study & Reason for exclusion \\
\hline Jepsen et al 2008 (35) & Same data of Meyle et al 2011 \\
\hline Pietruska et al 2012 (37) & Four years of follow-up \\
\hline Sculean et al 2007 (33) & Four years of follow-up \\
\hline
\end{tabular}

Tab.2 Cochrane Collaboration's tool for assessing risk of bias

\begin{tabular}{|c|c|c|c|c|c|c|c|}
\hline STUDY & $\begin{array}{l}\text { Adequate } \\
\text { sequence } \\
\text { generation }\end{array}$ & $\begin{array}{l}\text { Allocation } \\
\text { Concealment }\end{array}$ & Blinding & $\begin{array}{l}\text { Incomplete data } \\
\text { addressed }\end{array}$ & $\begin{array}{l}\text { Free of } \\
\text { selective } \\
\text { reporting }\end{array}$ & $\begin{array}{l}\text { Free of } \\
\text { other bias }\end{array}$ & $\begin{array}{l}\% \text { of yes } \\
\text { answers }\end{array}$ \\
\hline $\begin{array}{l}\text { Lekovic et al. } \\
2000 \text { (23) }\end{array}$ & Yes & Unclear & Yes & Unclear & Unclear & Yes & $50 \%$ \\
\hline $\begin{array}{l}\text { Velasquez-Plata } \\
\text { et al. } 2002(26)\end{array}$ & Yes & NA & Yes & Unclear & No & Yes & $50 \%$ \\
\hline $\begin{array}{l}\text { Zucchelli et al. } \\
2003 \text { (28) }\end{array}$ & Yes & Yes & Yes & Unclear & Yes & Yes & $83.3 \%$ \\
\hline $\begin{array}{l}\text { Gurinsky et al. } \\
2004(20)\end{array}$ & Yes & Unclear & Yes & Yes & Unclear & Yes & $66.6 \%$ \\
\hline $\begin{array}{l}\text { Sculean et al. } \\
2005(31)\end{array}$ & Yes & Unclear & Unclear & Yes & Yes & Yes & $66.6 \%$ \\
\hline $\begin{array}{l}\text { Bokan et al. } 2006 \\
\text { (34) }\end{array}$ & Yes & Yes & Yes & Unclear & Unclear & Unclear & $50 \%$ \\
\hline $\begin{array}{l}\text { Kuru et al. } 2006 \\
\text { (32) }\end{array}$ & Yes & Unclear & Yes & Yes & Yes & Yes & $83.3 \%$ \\
\hline $\begin{array}{l}\text { Guida et al. } 2007 \\
\text { (19) }\end{array}$ & Yes & NA & No & Yes & No & Yes & $50 \%$ \\
\hline $\begin{array}{l}\text { Yilmaz et al. } \\
2010(18)\end{array}$ & No & No & Yes & Yes & Yes & Yes & $66.6 \%$ \\
\hline $\begin{array}{l}\text { Meyle et al. } 2011 \\
\text { (36) }\end{array}$ & Yes & Yes & Yes & Yes & Yes & Yes & $100 \%$ \\
\hline $\begin{array}{l}\text { Cortellini \& } \\
\text { Tonetti } 2011 \text { (30) }\end{array}$ & Yes & Yes & Unclear & Yes & Yes & Yes & $83.3 \%$ \\
\hline $\begin{array}{l}\text { De Leonardis \& } \\
\text { Paolantonio } \\
2013 \text { (14) }\end{array}$ & Yes & Yes & Yes & Yes & Yes & Yes & $100 \%$ \\
\hline
\end{tabular}


Tab.3 Characteristics of included studies

\begin{tabular}{|c|c|c|c|c|c|c|c|}
\hline Author & $\begin{array}{l}\text { Stud } \\
\text { y } \\
\text { desi } \\
\text { gn }\end{array}$ & $\begin{array}{l}\text { Randomizat } \\
\text { ion }\end{array}$ & Masking & $\begin{array}{l}\text { Power } \\
\text { calculat } \\
\text { ion }\end{array}$ & Setting & Intervention & Follow-up \\
\hline $\begin{array}{l}\text { Lekovic et al. } \\
2000(23)\end{array}$ & $\mathrm{RCT}$ & Simple & $\begin{array}{l}\text { double } \\
\text { blind }\end{array}$ & NO & NA & EMD vsEMD+DBBM & 6 months \\
\hline $\begin{array}{l}\text { Velasquez- } \\
\text { Plata et al. } \\
2002(26)\end{array}$ & RCT & Simple & $\begin{array}{l}\text { single } \\
\text { blind }\end{array}$ & YES & NA & EMD vsEMD+DBBM & 6 to 8 months \\
\hline $\begin{array}{l}\text { Zucchelli et } \\
\text { al. } 2003(28)\end{array}$ & RCT & $\begin{array}{l}\text { Balanced } \\
\text { Blocks }\end{array}$ & $\begin{array}{l}\text { single } \\
\text { blind }\end{array}$ & YES & Univ/Private & EMD vs EMD+DBBM & 12-months \\
\hline $\begin{array}{l}\text { Gurinsky et } \\
\text { al. } 2004(20)\end{array}$ & RCT & Simple & $\begin{array}{l}\text { single } \\
\text { blind }\end{array}$ & NO & NA & EMD vs EMD+DFDBA & 6-months \\
\hline $\begin{array}{l}\text { Sculean et al. } \\
2005 \text { (31) }\end{array}$ & $\begin{array}{l}\mathrm{mR} \\
\mathrm{CT}\end{array}$ & Simple & NA & YES & NA & $\begin{array}{l}\text { EMD } \\
\text { EMD+Bioglass }\end{array}$ & 12-months \\
\hline $\begin{array}{l}\text { Bokan et al. } \\
2006(34)\end{array}$ & RCT & Simple & $\begin{array}{l}\text { single } \\
\text { blind }\end{array}$ & YES & NA & EMD vs EMD+SBG & 12-months \\
\hline $\begin{array}{l}\text { Kuru et al. } \\
2006(32)\end{array}$ & $\mathrm{RCT}$ & Simple & $\begin{array}{l}\text { single } \\
\text { blind }\end{array}$ & YES & NA & $\begin{array}{l}\text { EMD } \\
\text { EMD+Bioglass }\end{array}$ & 8-months \\
\hline $\begin{array}{l}\text { Guida et al. } \\
2007 \text { (19) }\end{array}$ & RCT & Simple & None & YES & University & EMD vs EMD+ABG & 12-months \\
\hline $\begin{array}{l}\text { Yilmaz et al. } \\
2010(18)\end{array}$ & RCT & Simple & $\begin{array}{l}\text { single- } \\
\text { blind }\end{array}$ & YES & University & EMD vs EMD+ABG & 12-months \\
\hline $\begin{array}{l}\text { Meyle et al. } \\
2011(36)\end{array}$ & $\begin{array}{l}\mathrm{mR} \\
\mathrm{CT}\end{array}$ & Simple & $\begin{array}{l}\text { Single- } \\
\text { blind }\end{array}$ & $\mathrm{NO}$ & NA & $\begin{array}{l}\text { EMD vs EMD+HA- } \\
\beta T C P\end{array}$ & 12-months \\
\hline $\begin{array}{l}\text { Cortellini \& } \\
\text { Tonetti } 2011 \\
(30)\end{array}$ & $\mathrm{RCT}$ & $\begin{array}{l}\text { Balanced } \\
\text { Blocks }\end{array}$ & NA & YES & Private & EMD vsEMD+DBBM & 12-months \\
\hline $\begin{array}{l}\text { De Leonardis } \\
\& \\
\text { Paolantonio } \\
2013 \text { (14) }\end{array}$ & RCT & Simple & $\begin{array}{l}\text { Single- } \\
\text { blind }\end{array}$ & YES & Private & $\begin{array}{l}\text { EMD vs EMD+HA- } \\
\beta T C P\end{array}$ & 24-months \\
\hline
\end{tabular}


Tab. 4 Patient's characteristics

\begin{tabular}{|c|c|c|c|c|c|c|c|}
\hline Author & $\begin{array}{l}\mathbf{N}^{\circ} \text { of } \\
\text { patients }\end{array}$ & $\begin{array}{l}\text { Gender } \\
\text { (M/F) }\end{array}$ & $\begin{array}{l}\text { Mean age of } \\
\text { patients (years) }\end{array}$ & $\begin{array}{l}\text { Age range of } \\
\text { patients (years) }\end{array}$ & $\begin{array}{l}\text { Tobacco } \\
\text { Smoke }\end{array}$ & $\begin{array}{l}\text { drop-out } \\
\text { (Y/N) }\end{array}$ & $\begin{array}{l}\text { Type of } \\
\text { periodontitis }\end{array}$ \\
\hline $\begin{array}{l}\text { Lekovic et al. } \\
2000 \text { (23) }\end{array}$ & 21 & $8(m) 13(f)$ & $39 \pm 1$ & NA & $12 / 9$ & NA & 0 \\
\hline $\begin{array}{l}\text { Velasquez- } \\
\text { Plata et al. } \\
2002(26)\end{array}$ & 16 & $7(\mathrm{~m}) 9(\mathrm{f})$ & NA & $6-65$ & $4 / 12$ & $\mathrm{mod} / \mathrm{adva}$ & 0 \\
\hline $\begin{array}{l}\text { Zucchelli et al. } \\
2003(28)\end{array}$ & 60 & $\begin{array}{l}26(m) \\
34(f)\end{array}$ & $46.2 \pm 8.4$ & $34-62$ & $20 / 40$ & Chronic & 0 \\
\hline $\begin{array}{l}\text { Gurinsky et al. } \\
2004(20)\end{array}$ & 40 & $\begin{array}{l}17(\mathrm{~m}) \\
23(\mathrm{f})\end{array}$ & NA & $19-76$ & NA & NA & 0 \\
\hline $\begin{array}{l}\text { Sculean et al. } \\
2005 \text { (31) }\end{array}$ & 30 & $\begin{array}{l}14(\mathrm{~m}) \\
16(\mathrm{f})\end{array}$ & NA & NA & $0 / 30$ & NA & 0 \\
\hline $\begin{array}{l}\text { Bokan et al. } \\
2006(34)\end{array}$ & 38 & $\begin{array}{l}17(\mathrm{~m}) \\
21(\mathrm{f})\end{array}$ & NA & NA & $9 / 29$ & NA & 1 \\
\hline $\begin{array}{l}\text { Kuru et al. } \\
2006 \text { (32) }\end{array}$ & 23 & $10(m) 13(f)$ & 44.7 & $32-58$ & $3 / 20$ & Chronic & 0 \\
\hline $\begin{array}{l}\text { Guida et al. } \\
2007 \text { (19) }\end{array}$ & 27 & $\begin{array}{l}13(\mathrm{~m}) \\
14(\mathrm{f})\end{array}$ & $46.3 \pm 8.7$ & $30-65$ & $4 / 23$ & Chronic/Ag. & 0 \\
\hline $\begin{array}{l}\text { Yilmaz et al. } \\
2010(18)\end{array}$ & 40 & $\begin{array}{l}24(m) \\
16(f)\end{array}$ & NA & $30-50$ & $0 / 40$ & Chronic & 0 \\
\hline $\begin{array}{l}\text { Meyle et al. } \\
2011 \text { (36) }\end{array}$ & 73 & $\begin{array}{l}23(\mathrm{~m}) \\
50(\mathrm{f})\end{array}$ & 46.9 & $21.1-66.7$ & $12 / 61$ & Chronic & 2 \\
\hline $\begin{array}{l}\text { Cortellini \& } \\
\text { Tonetti } 2011 \\
\text { (30) }\end{array}$ & 30 & $\begin{array}{l}15(m) \\
15(f)\end{array}$ & NA & NA & $4 / 26$ & NA & 0 \\
\hline $\begin{array}{l}\text { De Leonardis } \\
\& \text { Paolantonio } \\
2013 \text { (14) }\end{array}$ & 36 & $\begin{array}{l}15(m) \\
21(f)\end{array}$ & $45.3 \pm 5.9$ & $30-68$ & $0 / 36$ & NA & 2 \\
\hline
\end{tabular}


Tab. 5 Teeth and defects characteristics at baseline

\begin{tabular}{|c|c|c|c|c|c|}
\hline Author & $\mathbf{N}^{\circ}$ of teeth & Type tooth & $\mathbf{N}^{\circ}$ of defects & Type of defects & BOP+ (\%) \\
\hline Lekovic et al. 2000 & 42 & NA & 42 & 2-3 wall & NA \\
\hline $\begin{array}{l}\text { Velasquez-Plata et al. } \\
2002(26)\end{array}$ & 32 & Anterior/posterior & 32 & 2-3 wall & NA \\
\hline $\begin{array}{l}\text { Zucchelli et al. } 2003 \\
\text { (28) }\end{array}$ & 60 & Anterior/posterior & 60 & NA & NA \\
\hline $\begin{array}{l}\text { Gurinsky et al. } 2004 \\
\text { (20) }\end{array}$ & 67 & Anterior/posterior & 34EMD 33(EMD+DFDBA) & 1-2-3-wall & NA \\
\hline $\begin{array}{l}\text { Sculean et al. } 2005 \\
\text { (31) }\end{array}$ & 30 & NA & 30 & 1-2-3-wall & $\begin{array}{l}50 \text { EMD } \\
52(E M D+B G)\end{array}$ \\
\hline Bokan et al. 2006 (34) & 38 & Anterior/posterior & 38 & 1-2-3-wall & $\begin{array}{l}43 \text { EMD } \\
42(\text { EMD+SBG) }\end{array}$ \\
\hline Kuru et al. 2006 (32) & NA & NA & 40 & 1-2 wall & NA \\
\hline Guida et al. 2007 (19) & 28 & Anterior/posterior & 28 & 1-2 wall & NA \\
\hline Yilmaz et al. 2010 (18) & 40 & Anterior/posterior & 40 & 2-3 wall & $\begin{array}{l}49 \text { EMD } \\
50(E M D+A B G)\end{array}$ \\
\hline Meyle et al. 2011 (36) & 73 & NA & 73 & 1-2 wall & NA \\
\hline $\begin{array}{l}\text { Cortellini \& Tonetti } \\
2011(30)\end{array}$ & 30 & NA & 30 & combination 1-2-3-wall & NA \\
\hline $\begin{array}{l}\text { De Leonardis \& } \\
\text { Paolantonio } 2013 \text { (14) }\end{array}$ & 68 & NA & 68 & 1-2 wall & NA \\
\hline
\end{tabular}


Tab.6 Clinical and Intra-surgical characteristic of defects at baseline

\begin{tabular}{|c|c|c|c|c|c|c|c|c|}
\hline Authors & $\begin{array}{l}\text { PD } \\
(\mathrm{mm})\end{array}$ & $\begin{array}{l}\text { CAL } \\
(\mathrm{mm})\end{array}$ & $\begin{array}{l}\text { REC } \\
(\mathrm{mm})\end{array}$ & $\begin{array}{l}\text { CEJ-BD } \\
(\mathrm{mm})\end{array}$ & INFRA (mm) & $\begin{array}{l}\text { PPT } \\
\text { (Y/N) }\end{array}$ & MIST/CF & $\begin{array}{l}\text { Antibio } \\
\text { (Y/N) }\end{array}$ \\
\hline $\begin{array}{l}\text { Lekovic et al. } \\
2000\end{array}$ & $\begin{array}{l}\text { EMD }(7.33 \pm 1.22 \\
\text { EMD+DBBM( } \\
7.74 \pm 1.41 \mathrm{v}) \\
(7.16 \quad \pm 1.20 \quad \text { I) } \\
7.18 \pm 1.28 \mathrm{I})\end{array}$ & NA & NA & NA & NA & $\mathrm{N}$ & CF & $\mathrm{Y}$ \\
\hline $\begin{array}{l}\text { Velasquez- } \\
\text { Prata et al. } 2002 \\
(26)\end{array}$ & $\begin{array}{l}\operatorname{EMD}(6.6 \pm 1.3) \\
\operatorname{EMD+DBBM}(6.9 \pm 0.9)\end{array}$ & NA & NA & NA & NA & $\mathrm{N}$ & CF & $\mathrm{Y}$ \\
\hline $\begin{array}{l}\text { Zucchelli et al. } \\
2003(28)\end{array}$ & $\begin{array}{l}\operatorname{EMD}(9.2 \pm 1.1) \\
\operatorname{EMD+DBBM}(9.4 \pm 1.1)\end{array}$ & $\begin{array}{l}\text { EMD }(10.1 \pm 1.4) \\
\text { EMD+DBBM( } \\
10.3 \pm 1.5)\end{array}$ & $\begin{array}{l}\mathrm{EMD}(0.9 \pm 0.9) \\
\mathrm{EMD}+\mathrm{DBBM}( \\
0.9 \pm 0.7)\end{array}$ & $\begin{array}{l}\mathrm{EMD}(11.7 \pm 1.7) \\
\mathrm{EMD}+\mathrm{DFDBA}(11.4 \pm 1.7)\end{array}$ & $\begin{array}{l}\operatorname{EMD}(6.8 \pm 0.9) \\
\operatorname{EMD+DBBM}(6.7 \pm 1.0)\end{array}$ & Y SPPT & CF & $\mathrm{Y}$ \\
\hline $\begin{array}{l}\text { Gurinsky et al. } \\
2004(20)\end{array}$ & $\begin{array}{l}\text { EMD( } 7.5 \pm 0.3) \\
\text { EMD+DFDBA( } \\
7.5 \pm 0.3)\end{array}$ & $\begin{array}{l}\text { EMD }(8.1 \pm 0.3) \\
\text { EMD+DFDBA( } \\
8.2 \pm 0.3)\end{array}$ & $\begin{array}{l}\text { EMD( } 0.6 \pm 0.0) \\
\text { EMD+DFDBA }( \\
0.7 \pm 0.0)\end{array}$ & $\mathrm{NA}$ & $\begin{array}{l}\text { EMD }(4.9 \pm 0.3) \\
\text { EMD+DFDBA( } 5.2 \pm 0.3)\end{array}$ & $\mathrm{N}$ & CF & $\mathrm{NA}$ \\
\hline $\begin{array}{l}\text { Sculean et al. } \\
2005(31)\end{array}$ & $\begin{array}{l}\mathrm{EMD}(8.5 \pm 1.5) \\
\mathrm{EMD}+\mathrm{BG}(8.5 \pm 1.1)\end{array}$ & $\begin{array}{l}\text { EMD }(10.2 \pm 2.1) \\
\text { EMD+BG }(10.4 \pm 1.5)\end{array}$ & $\begin{array}{l}\mathrm{EMD}(1.5 \pm 1.4) \\
\mathrm{EMD+BG}(1.9 \pm 1.1)\end{array}$ & $\begin{array}{l}\mathrm{EMD}(11.2 \pm 1.4) \\
\mathrm{EMD}+\mathrm{BG}(11.3 \pm 1.3\end{array}$ & $\begin{array}{l}\operatorname{EMD}(4.1 \pm 1.1) \\
\operatorname{EMD}+\operatorname{BG}(4.3 \pm 1.0)\end{array}$ & $\mathrm{N}$ & $\mathrm{CF}$ & $\mathrm{Y}$ \\
\hline $\begin{array}{l}\text { Bokan et al. } \\
2006(34)\end{array}$ & $\begin{array}{l}\operatorname{EMD}(8.6 \pm 1.3) \\
\text { EMD+SBG( } 8.6 \pm 1.4)\end{array}$ & $\begin{array}{l}\operatorname{EMD}(10.3 \pm 1.8) \\
\operatorname{EMD} \quad \text { SBG } \\
9.8 \pm 1.3)\end{array}$ & $\begin{array}{l}\operatorname{EMD}(2.4 \pm 2.0) \\
\operatorname{EMD} \quad \text { SBG } \\
1.3 \pm 1.2)\end{array}$ & NA & NA $\quad$ SPPT & & MIST & $\mathrm{Y}$ \\
\hline $\begin{array}{l}\text { Kuru et al. } 2006 \\
\text { (32) }\end{array}$ & $\begin{array}{l}\mathrm{EMD}(9.47 \pm 0.81) \\
\mathrm{EMD}+\mathrm{BG}(9.77 \pm 0.01)\end{array}$ & NA & NA & $\mathrm{NA}$ & $\begin{array}{l}\mathrm{EMD}(5.68 \pm 0.59) \\
\mathrm{EMD}+\mathrm{BG}(5.48 \pm 0.62)\end{array}$ & $\mathrm{N}$ & $\mathrm{CF}$ & $\mathrm{Y}$ \\
\hline $\begin{array}{l}\text { Guida et al. } \\
2007 \text { (19) }\end{array}$ & $\begin{array}{l}\operatorname{EMD}(9.6 \pm 1.7) \\
\operatorname{EMD}+A B G(9.1 \pm 1.6)\end{array}$ & $\begin{array}{l}\mathrm{EMD}(10.6 \pm 1.3) \\
\mathrm{EMD}+\mathrm{ABG}( \\
10.3 \pm 1.5)\end{array}$ & $\begin{array}{l}\operatorname{EMD}(1.1 \pm 1.0) \\
\operatorname{EMD}+A B G(1.1 \pm 0.9)\end{array}$ & $\begin{array}{l}\operatorname{EMD}(11.7 \pm 1.7) \\
\operatorname{EMD}+A B G(10.9 \pm 2.0)\end{array}$ & $\begin{array}{l}\mathrm{EMD}(6.2 \pm 2.0) \\
\mathrm{EMD}+\mathrm{ABG}(7.0 \pm 1.2)\end{array}$ & MPPT & CF & $\mathrm{Y}$ \\
\hline $\begin{array}{l}\text { Yilmaz et al. } \\
2010 \text { (18) }\end{array}$ & $\begin{array}{l}\operatorname{EMD}(8.2 \pm 0.7) \\
\text { EMD+ABG( } 8.4 \pm 1.2)\end{array}$ & $\begin{array}{l}\mathrm{EMD}(11.3 \pm 0.9) \\
\mathrm{EMD}+\mathrm{ABG}( \\
11.7 \pm 1.0)\end{array}$ & $\begin{array}{l}\mathrm{EMD}(3.1 \pm 1.1) \\
\mathrm{EMD}+\mathrm{ABG}(3.3 \pm 1.5)\end{array}$ & NA & $\begin{array}{l}\mathrm{EMD}(5.2 \pm 0.7) \\
\mathrm{EMD}+\mathrm{ABG}(5.4 \pm 1.0)\end{array}$ & NA & CF & $\mathrm{Y}$ \\
\hline \multirow{2}{*}{$\begin{array}{l}\text { Meyle et al. } \\
2011(36)\end{array}$} & $\operatorname{EMD}(7.1 \pm 1.5)$ & $\operatorname{EMD}(10.1 \pm 2.2)$ & $\operatorname{EMD}(3.0 \pm 1.6)$ & NA & NA & SPPT & $\mathrm{CF}$ & NA \\
\hline & $\begin{array}{l}\mathrm{EMD}+\mathrm{HA}+\beta \mathrm{TCP}( \\
6.9 \pm 1.8)\end{array}$ & $\begin{array}{l}\mathrm{EMD}+\mathrm{HA}+\beta \mathrm{TCP}( \\
9.3 \pm 2.1)\end{array}$ & $\begin{array}{l}\mathrm{EMD}+\mathrm{HA}+\beta \mathrm{TCP}( \\
2.4 \pm 1.3)\end{array}$ & & & & & \\
\hline $\begin{array}{l}\text { Cortellini \& } \\
\text { Tonetti } 2011 \\
\text { (30) }\end{array}$ & $\begin{array}{l}\operatorname{EMD}(7.8 \pm 0.9) \\
\operatorname{EMD+DBBM}(7.3 \pm 1.2)\end{array}$ & $\begin{array}{l}\text { EMD( } 9.9 \pm 1.3) \\
\text { EMD+DBBM( } \\
10.1 \pm 2.4)\end{array}$ & $\begin{array}{l}\text { EMD( 2.1 } \pm 1.4) \\
\text { EMD+DBBM( } \\
2.9 \pm 1.8)\end{array}$ & $\begin{array}{l}\operatorname{EMD}(10.5 \pm 1.5) \\
\operatorname{EMD}+\operatorname{DBBM}(10.9 \pm 2.2)\end{array}$ & $\begin{array}{ll}\text { EMD( } & 5.3 \pm 1.0) \\
\text { EMD+DBBM( } 5.2 \pm 1.4)\end{array}$ & $\mathrm{Y}$ & MIST & $\mathrm{N}$ \\
\hline $\begin{array}{l}\text { De Leonardis \& } \\
\text { Paolantonio } \\
2013(14)\end{array}$ & $\begin{array}{l}\mathrm{EMD}+\mathrm{HbTC}(8.8 \pm 1.0) \\
\operatorname{EMD}(8.7 \pm 1.0)\end{array}$ & $\begin{array}{l}\text { EMD+HbTC( } \\
9.4 \pm 1.1) \\
\operatorname{EMD}(9.2 \pm 1.0)\end{array}$ & $\begin{array}{l}\text { EMD+HbTC( } \\
0.6 \pm 0.4) \\
\text { EMD }(0.5 \pm 0.4)\end{array}$ & $\begin{array}{l}\mathrm{EMD}+\mathrm{HbTC}(6.7 \pm 1.0) \\
\operatorname{EMD}(6.8 \pm 0.9)\end{array}$ & $\begin{array}{l}\mathrm{EMD}+\mathrm{HbTC}(4.5 \pm 1.8) \\
\operatorname{EMD}(5.2 \pm 1.4)\end{array}$ & $\mathrm{M} / \mathrm{S}$ & CF & $\mathrm{Y}$ \\
\hline
\end{tabular}


Tab. 7 Changes in BOP, PD, CAL and REC

\begin{tabular}{|c|c|c|c|c|}
\hline Authors & BOP (\%) & PD change (mm) & CAL change $(\mathrm{mm})$ & REC change (mm) \\
\hline \multirow{2}{*}{$\begin{array}{l}\text { Lekovic et al. } \\
2000 \text { (23) }\end{array}$} & \multirow{2}{*}{ NA } & $\begin{array}{l}\text { EMD }(1.91 \pm 1.42 v) \\
\text { EMD+DBBM }(3.43 \pm 1.32 v)\end{array}$ & $\begin{array}{l}\text { EMD }(1.72 \pm 1.33 \mathrm{v}) \\
\text { EMD+DBBM }(3.13 \pm 1.41 \mathrm{v})\end{array}$ & $\begin{array}{l}\text { EMD }(1.26 \pm 1.34 \mathrm{v}) \\
\text { EMD+DBBM }(1.31 \pm 1.26 \mathrm{v})\end{array}$ \\
\hline & & $\begin{array}{l}\text { EMD }(1.85 \pm 1.38 \mathrm{l}) \\
\text { EMD+DBBM }(3.36 \pm 1.135 \mathrm{I})\end{array}$ & $\begin{array}{l}\text { EMD }(1.75 \pm 1.37 \mathrm{I}) \\
\text { EMD+DBBM }(3.11 \pm 1.39 \mathrm{I})\end{array}$ & $\begin{array}{l}\text { EMD }(1.22 \pm 1.28 \mathrm{I}) \\
\text { EMD+DBBM }(1.29 \pm 1.24 \mathrm{I})\end{array}$ \\
\hline $\begin{array}{l}\text { Velasquez-Plata } \\
\text { et al. } 2002(26)\end{array}$ & NA & $\begin{array}{l}\text { EMD (3.8 } \pm 1.2) E M D+D B B M \\
(4.0 \pm 0.8)\end{array}$ & $\begin{array}{l}\text { EMD }(2.9 \pm 0.9) \\
\text { EMD+DBBM(3.4 } \pm 0.9)\end{array}$ & $\begin{array}{l}\text { EMD }(0.8 \pm 0.8) \text { EMD+DBBM } \\
(0.3 \pm 0.6)\end{array}$ \\
\hline $\begin{array}{l}\text { Zucchelli et al. } \\
2003(28)\end{array}$ & NA & $\begin{array}{l}\text { EMD (5.8 } \pm 0.8) \text { EMD+DBBM } \\
(6.2 \pm 0.4)\end{array}$ & $\begin{array}{l}\text { EMD (4.9 } \pm 1.0) \text { EMD+DBBM } \\
(5.8 \pm 1.1)\end{array}$ & $\begin{array}{l}\text { EMD }(0.9 \pm 0.5) \text { EMD+DBBM } \\
(0.4 \pm 0.6)\end{array}$ \\
\hline $\begin{array}{l}\text { Gurinsky et al. } \\
2004(20)\end{array}$ & NA & $\begin{array}{l}\text { EMD (4.0 } \pm 0.3) \text { EMD+FDBA } \\
(3.6 \pm 0.2)\end{array}$ & $\begin{array}{l}\text { EMD (3.2 } \pm 0.3) \text { EMD+FDBA } \\
(3.0 \pm 0.3)\end{array}$ & $\begin{array}{l}\text { EMD }(0.7 \pm 0.2) \\
\text { EMD+FDBA(0.5 } \pm 0.3)\end{array}$ \\
\hline $\begin{array}{l}\text { Sculean et al. } \\
2005(31)\end{array}$ & $\begin{array}{l}\text { EMD(22); } \\
\text { EMD+BG(28) }\end{array}$ & $\begin{array}{l}\text { EMD (4.5 } \pm 2.0) \text { EMD+BG } \\
(4.2 \pm 1.4)\end{array}$ & $\begin{array}{l}\text { EMD (3.9 } \pm 1.8) \text { EMD+BG } \\
(3.2 \pm 1.7)\end{array}$ & $\begin{array}{l}\text { EMD }(0.9 \pm 0.7) \text { EMD+BG } \\
(1.1 \pm 0.8)\end{array}$ \\
\hline $\begin{array}{l}\text { Bokan et al. } 2006 \\
\text { (34) }\end{array}$ & $\begin{array}{l}\operatorname{EMD}(25) \\
\text { EMD+SBG(21) }\end{array}$ & $\begin{array}{l}\text { EMD }(3.9 \pm 1.3) \\
\text { EMD+SBG(4.1 } \pm 1.2)\end{array}$ & $\begin{array}{l}\text { EMD }(3.7 \pm 1.0) \text { EMD+ } \\
\text { SBG(4.0 } \pm 1.0)\end{array}$ & $\begin{array}{l}\text { EMD (0.7 } \pm 1.3) \text { EMD+ SBG } \\
(0.7 \pm 1.1)\end{array}$ \\
\hline $\begin{array}{l}\text { Kuru et al. } 2006 \\
(32)\end{array}$ & NA & $\begin{array}{l}\text { EMD }(5.03 \pm 0.89) \text { EMD+BG } \\
(5.73 \pm 0.80)\end{array}$ & $\begin{array}{l}\text { EMD (4.06 } \pm 1.06) \text { EMD+BG } \\
(5.17 \pm 0.85)\end{array}$ & $\begin{array}{l}\text { EMD }(0.97 \pm 0.24) \text { EMD+BG } \\
(0.56 \pm 0.18)\end{array}$ \\
\hline $\begin{array}{l}\text { Guida et al. } 2007 \\
\text { (19) }\end{array}$ & NA & $\begin{array}{l}\text { EMD }(5.6 \pm 1.7) E M D+A B G \\
(5.1 \pm 1.7)\end{array}$ & $\begin{array}{l}\text { EMD (4.6 } \pm 1.3) \text { EMD+ABG } \\
(4.9 \pm 1.8)\end{array}$ & $\begin{array}{l}\text { EMD (1.1 } \pm 0.7) E M D+A B G \\
(0.3 \pm 0.8)\end{array}$ \\
\hline $\begin{array}{l}\text { Yilmaz et al. } 2010 \\
\text { (18) }\end{array}$ & $\begin{array}{l}\operatorname{EMD}(16) \\
\text { EMD+ABG(15) }\end{array}$ & $\begin{array}{l}\text { EMD }(4.6 \pm 0.4) E M D+A B G \\
(5.6 \pm 0.9)\end{array}$ & $\begin{array}{l}\text { EMD (3.4 } \pm 0.8) E M D+A B G \\
(4.2 \pm 1.1)\end{array}$ & $\begin{array}{l}\text { EMD }(1.2 \pm 0.8) E M D+A B G \\
(1.4 \pm 0.9)\end{array}$ \\
\hline $\begin{array}{l}\text { Meyle et al. } 2011 \\
\text { (36) }\end{array}$ & NA & $\begin{array}{l}\text { EMD }(2.9 \pm 1.8) \text { EMD+HA- } \\
\beta T C P(2.8 \pm 2.1)\end{array}$ & $\begin{array}{l}\text { EMD }(1.69 \pm 2.1) \text { EMD+HA- } \\
\text { BTCP }(1.9 \pm 1.7)\end{array}$ & $\begin{array}{l}\text { EMD }(0.97 \pm 1.1) \text { EMD+HA- } \\
\beta T C P(1.11 \pm 1.3)\end{array}$ \\
\hline $\begin{array}{l}\text { Cortellini \& } \\
\text { Tonetti } 2011 \text { (30) }\end{array}$ & NA & $\begin{array}{l}\text { EMD (4.4 } \pm 1.2) \text { EMD+DBBM } \\
(4.0 \pm 1.3)\end{array}$ & $\begin{array}{l}\text { EMD (4.1 } \pm 1.2) \text { EMD+DBBM } \\
(3.7 \pm 1.3)\end{array}$ & $\begin{array}{l}\text { EMD }(0.3 \pm 0.5) \text { EMD+DBBM } \\
(0.3 \pm 0.7)\end{array}$ \\
\hline $\begin{array}{l}\text { De Leonardis \& } \\
\text { Paolantonio } 2013 \\
\text { (14) }\end{array}$ & NA & $\begin{array}{l}\text { EMD (3.7 } \pm 0.7) \text { EMD+HbTC } \\
(4.2 \pm 0.6)\end{array}$ & $\begin{array}{l}\text { EMD (2.9 } \pm 0.7) \text { EMD+HbTC } \\
(3.6 \pm 0.9)\end{array}$ & $\begin{array}{l}\text { EMD }(0.8 \pm 0.4) \text { EMD }+\mathrm{HbTC} \\
(0.6 \pm 0.4)\end{array}$ \\
\hline
\end{tabular}


Tab.8 Survival rate and complications

\begin{tabular}{|c|c|c|c|c|c|c|}
\hline Authors & $\begin{array}{l}\text { Tooth } \\
\text { loss }\end{array}$ & $\begin{array}{l}\text { Survival } \\
\text { Rate }\end{array}$ & $\begin{array}{l}\text { Flap } \\
\text { dehiscences }\end{array}$ & $\begin{array}{l}\text { Primary would healing of } \\
\text { interdental space }\end{array}$ & $\begin{array}{l}N^{\circ} \text { of residual } \\
\text { pockets } \geq 5 \mathrm{~mm}\end{array}$ & $\begin{array}{l}\mathbf{N}^{\circ} \text { of sites } \\
\text { with CAL loss }\end{array}$ \\
\hline $\begin{array}{l}\text { Lekovic et al. } \\
2000 \text { (23) }\end{array}$ & 0 & $100 \%$ & 0 & NA & NA & NA \\
\hline $\begin{array}{l}\text { Velasquez- } \\
\text { Plata et al. } 2002 \\
\text { (26) }\end{array}$ & 0 & $100 \%$ & 0 & NA & NA & NA \\
\hline $\begin{array}{l}\text { Zucchelli et al. } \\
2003(28)\end{array}$ & 0 & $100 \%$ & 0 & NA & NA & NA \\
\hline $\begin{array}{l}\text { Gurinsky et al. } \\
2004(20)\end{array}$ & 0 & $100 \%$ & 0 & NA & NA & NA \\
\hline $\begin{array}{l}\text { Sculean et al. } \\
2005(31)\end{array}$ & 0 & $100 \%$ & 0 & NA & NA & 1 \\
\hline $\begin{array}{l}\text { Bokan et al. } \\
2006(34)\end{array}$ & 0 & $100 \%$ & 0 & Yes & NA & 0 \\
\hline $\begin{array}{l}\text { Kuru et al. } 2006 \\
\text { (32) }\end{array}$ & 0 & $100 \%$ & 0 & NA & NA & NA \\
\hline $\begin{array}{l}\text { Guida et al. } \\
2007 \text { (19) }\end{array}$ & 0 & $100 \%$ & NA & NA & NA & 0 \\
\hline $\begin{array}{l}\text { Yilmaz et al. } \\
2010(18)\end{array}$ & 0 & $100 \%$ & NA & NA & NA & NA \\
\hline $\begin{array}{l}\text { Meyle et al. } \\
2011(36)\end{array}$ & 0 & $100 \%$ & NA & NA & NA & NA \\
\hline $\begin{array}{l}\text { Cortellini \& } \\
\text { Tonetti } 2011 \\
\text { (30) }\end{array}$ & 0 & $100 \%$ & 0 & $29 / 30$ & NA & 0 \\
\hline $\begin{array}{l}\text { De Leonardis \& } \\
\text { Paolantonio } \\
2013 \text { (14) }\end{array}$ & 0 & $100 \%$ & NA & Yes & NA & NA \\
\hline
\end{tabular}




\section{Footnotes}

NA : not available

EMD : enamel matrix derivative

DFDBA : demineralized freeze-dried bone allograft

ABG : Autogenous bone graft

SBG: Silicate bone graft

HA- $\beta$ TCP:hydroxyapatite and $\beta$-tricalcium phosphate

DBBM: deproteinized bovine bone mineral

RCT: Randomized clinical trial

m-RCT: multicentre randomized clinical trial

$\mathrm{m}$ : male

f: female

mod/adva: moderate/advanced

Ag: aggressive

BoP+ : bleeding on probing

$\mathrm{PD}$ : probing depth

CAL : clinical attachment level

REC : gingival recession

CEJ-BD : vertical distance from CEJ to bone defect

INFRA : intrabony component

PPT: papilla preservation technique

MIST: Minimally invasive surgical technique

CF: conventional flap

SPPT: simplified papilla preservation technique

MPPT: modified papilla preservation technique

$\mathrm{Y}$ : Yes

$\mathrm{N}$ : No 
Fig.1 Preferred reporting items for Systematic Reviews and Meta Analyses (PRISMA) flow diagram

Identification

Screening

Eligibility

Inclusion
7.441 titles identified through MEDLINE via PubMed

3.258 titles identified through EMBASE via Ovid 1.589 titles identified through THE COCHRANE LIBRARY

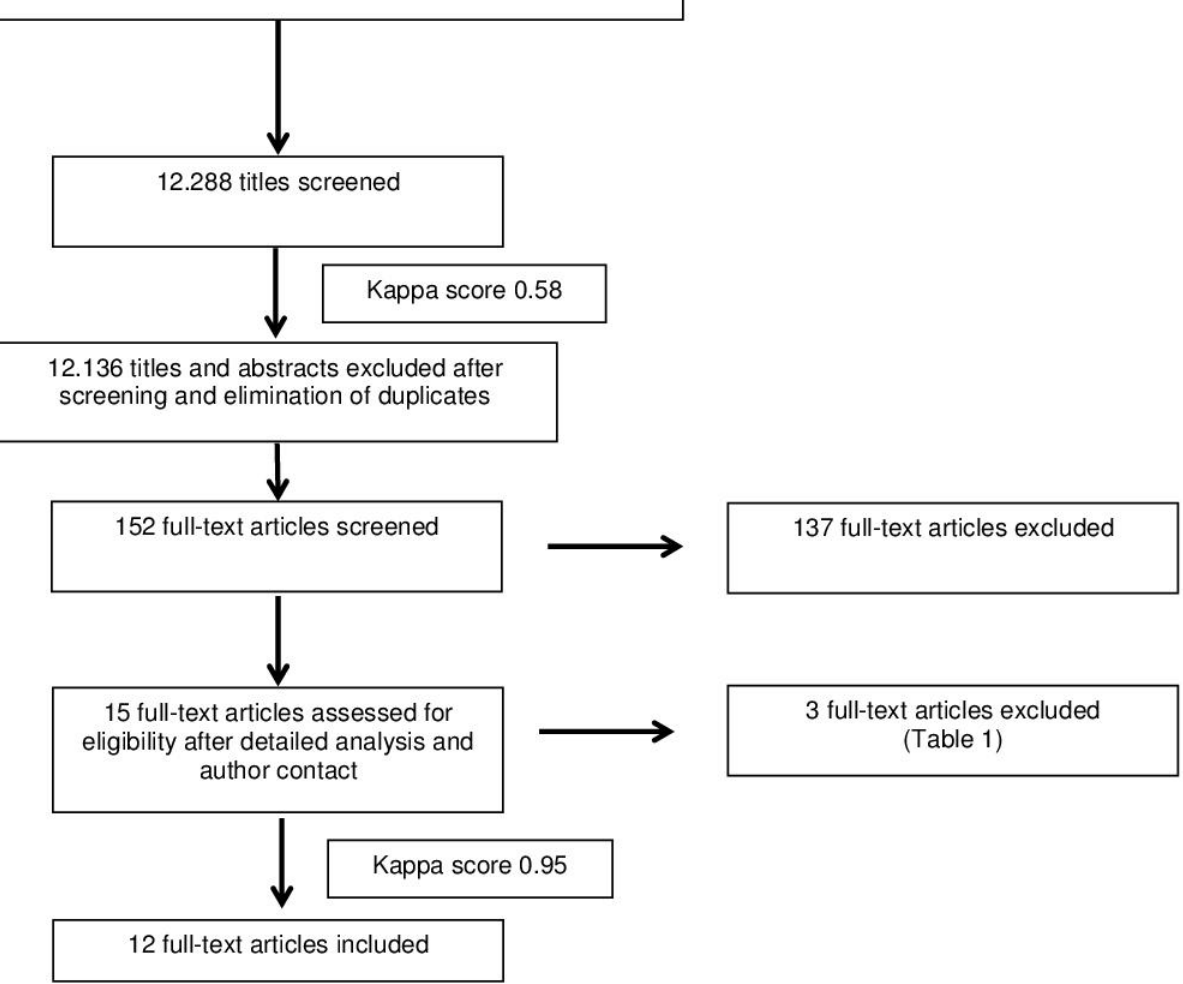


Fig. 2 Forest plot from fixed effects of meta-analysis evaluating the differences in PD reduction (in $\mathrm{mm}$ ) after surgical treatment using EMD and bone graft or EMD alone (weighted mean difference, 95\% Cl)

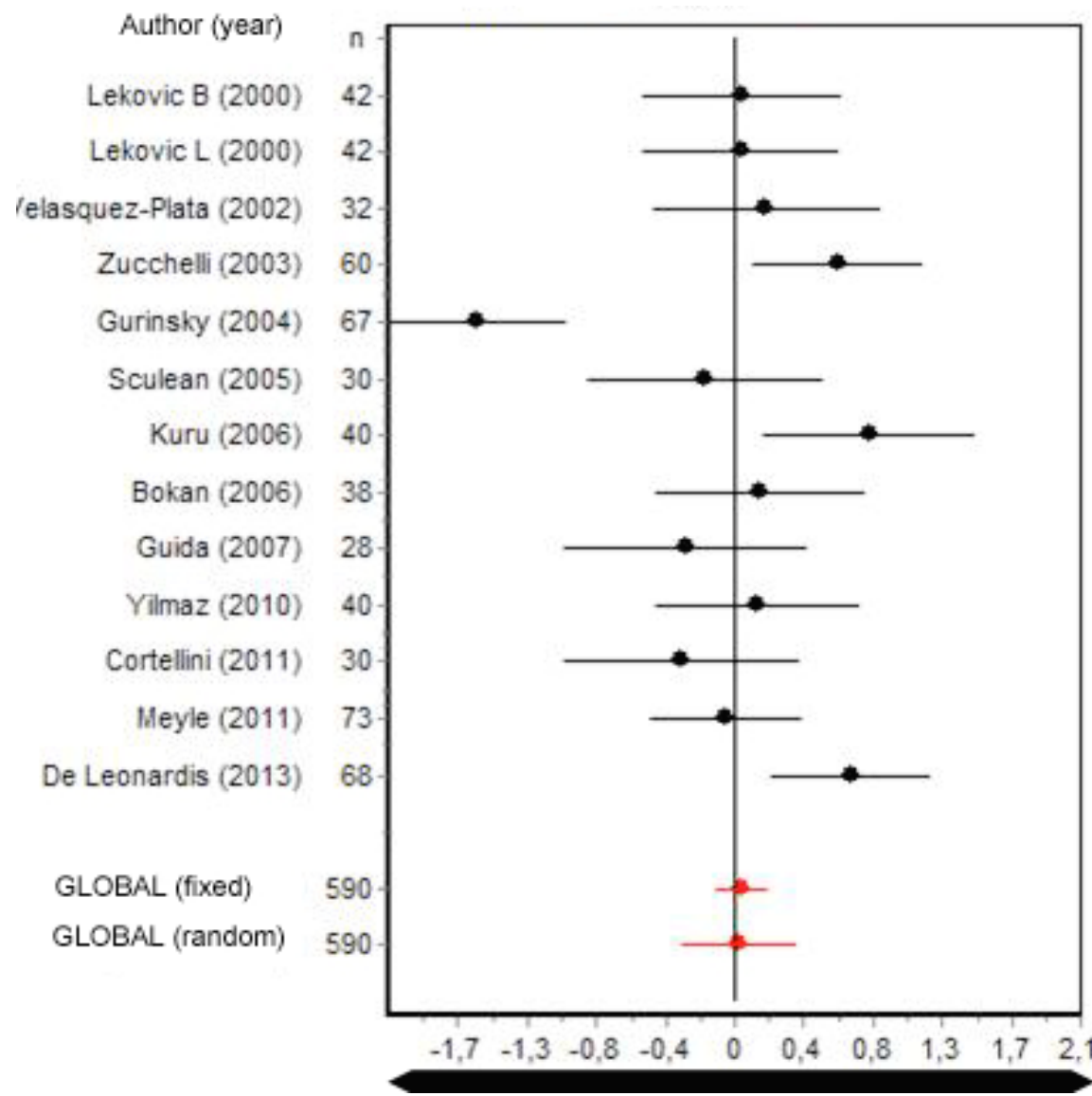

Favours EMD

Favours EMD + Bone Grafts 
Fig.3 Forest plot from fixed effects of meta-analysis evaluating the differences in CAL gain (in $\mathrm{mm}$ ) after surgical treatment using EMD and bone graft or EMD alone (weighted mean difference, $95 \% \mathrm{Cl}$ )

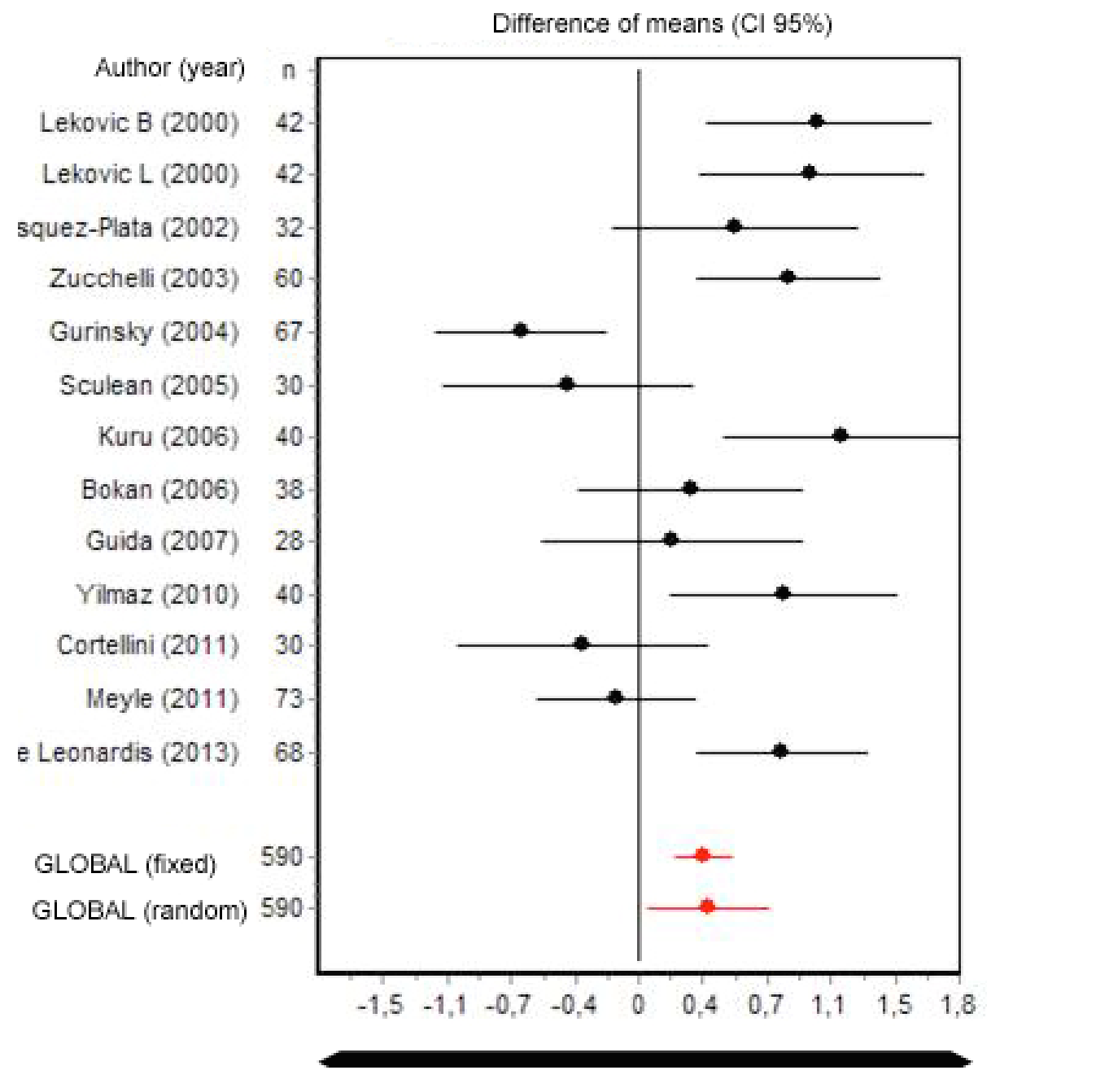

Favours EMD

Favours EMD + Bone Grafts 
Fig.4 Forest plot from fixed effects of meta-analysis evaluating the differences in REC increase (in $\mathrm{mm}$ ) after surgical treatment using EMD and bone graft or EMD alone (weighted mean difference, 95\% Cl)

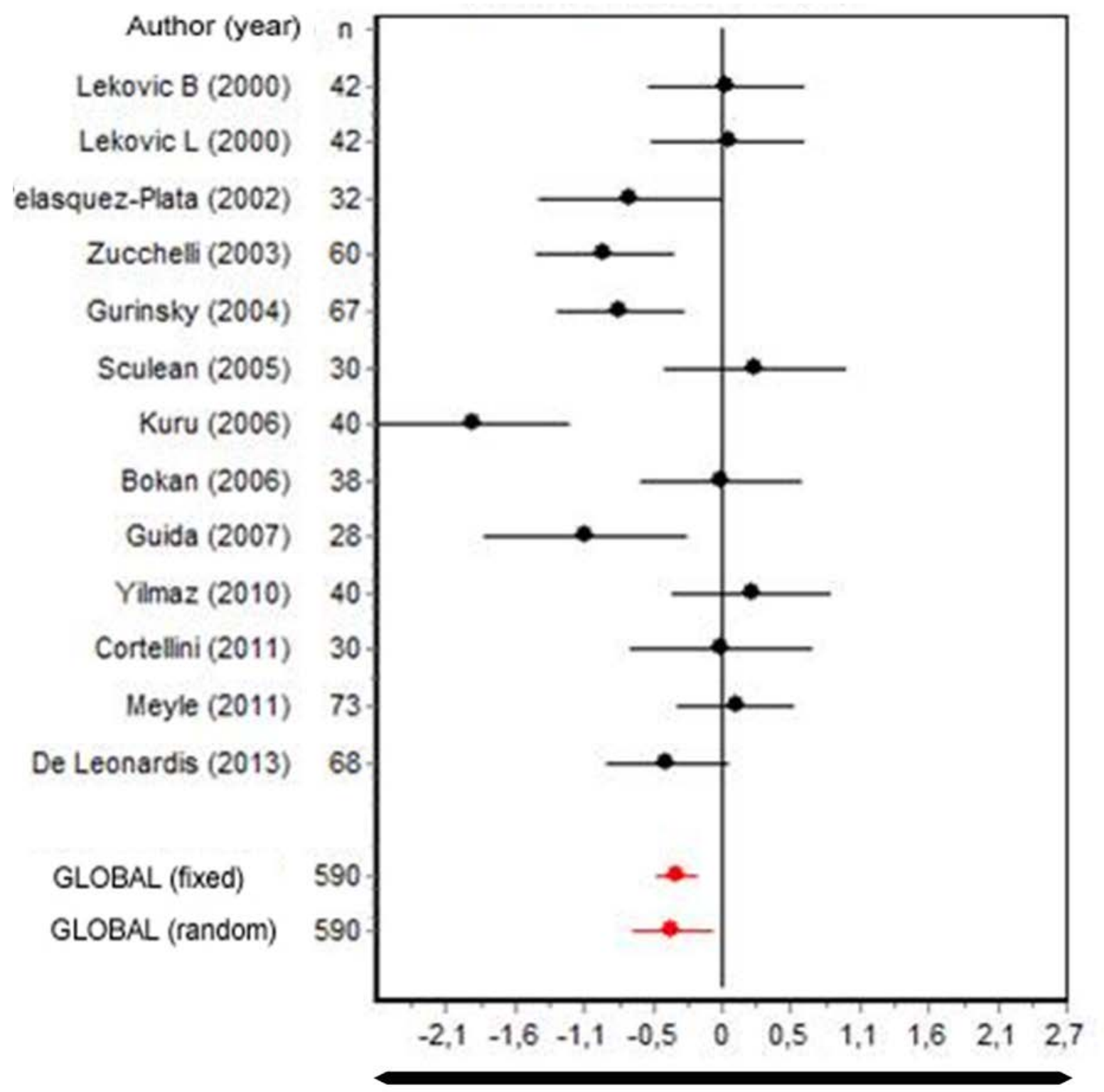

Favours EMD

Favours EMD + Bone Grafts 